\title{
NEW RECORDS OF STYRAX AND CASUARINA FROM THE SOLOMON ISLANDS
}

\author{
C. G. G. J. van Steenis
}

\section{STYRACACEAE}

Styrax agrestis (Lour.) G. Don; cf. Van Steenis in Bull. Jard. Bot. Buitenzorg III. 12: 224. 1932.

Solomon Islands: Ysabel Island, common in mountain forest on Mt. Marescott, ca. 1000 m. alt., Dec. 2, 1932, L. J. Brass 3261, a slender, small tree, flowers white. - Guadalcanal Island, Vuolo, Mt. Tutive, common in rainforest, growing on top of mountains, ca. $1200 \mathrm{~m}$. alt., April 4, 1931, S. F. Kajewski 2499, a small tree, up to 12 m., petals white, stamens cream, fruit $18 \times 7 \mathrm{~mm}$., finely hairy, with pointed apex, twig galls present, v.n. "born-borna." Bismarck Archipelago: New Ireland (Neu Mecklenburg), Ugana District, Abhang des Lelet Gebirges, 150 m. alt., Mai 12, 1938, Father G. Peekel 106, "Baum 12 m. hoch, Blüten weiss, wächst auch in der Ebene und blüht schon wenn nur 5-6 m. hoch, auf gelbem Lehmboden."

This species was hitherto known from the Indochinese Peninsula, Borneo, Celebes, Moluccas (Ceram) and New Guinea. No representative of the Styracaeae was previously known to occur east of New Guinea.

In Malaysia it occurs mostly at low altitude, the highest recorded ones being $500 \mathrm{~m}$. in Celebes and $700 \mathrm{~m}$. in Ceram. It is noteworthy that in this eastern extension of range the species occurs at higher altitudes, 1000-1200 m.

Recently Hosokawa, Trans. Nat. Hist. Soc. Formosa 28: 65. 1938, described a new species of Styrax from the islet of Korror, Palau, Micronesia, vix. S. rostratus Hosokawa. This species he placed in the affinity of $S$. Warburgii Perk., which I have reduced to S. agrestis G. Don (Bull. Jard. Bot. Btzg. III. 12: 224. 1932). Hosokawa's description of the first representative of the family to be recorded from Micronesia, agrees well with that of $S$. agrestis and, although I have not seen any Korror specimen, I am convinced that it must be reduced to the widely distributed S. agrestis. Phytogeographically the Palau locality fits well into the area of Styrax agrestis G. Don. 


\section{CASUARINACEAE}

Casuarina sumatrana Jungh. \& de Vriese.

Solomon Islands: San Cristoval Island, Hinua-haoro, common in mountain rainforest, growing usually on crests of spurs, ca. $900 \mathrm{~m}$. alt., Sept. 16, 1932, L. J. Brass 2871 , a tree $20 \mathrm{~m}$. or more, with stout, spreading branches, thin, brown, furrowed, suberose bark, red within, and with very heavy reddish wood. Bark of branches warted. Branchlets stiff, bright green. Young growth yellowish.

I fail to see any differences between this specimen and the rather abundant Malaysian material in the Buitenzorg Herbarium. The species was hitherto known from Sumatra, Borneo, Philippines and Celebes, and probably occurs also in New Guinea.

At the time that the species was described it seemed phytogeographically strange to detect in Sumatra an endemic inland species of a genus principally centering in Australia. As has been shown in numerous cases the absence of collections was the principal cause of this assumed peculiar distribution, and later collections have revealed a much wider range. Now all the Malaysian species of Casuarina are connected phytogeographically with the Australian-Papuan districts. Casuarina equisetifolia is a widely distributed shore tree, $C$. sumatrana occurs throughout the Archipelago, C. Rumphiana is also known from Celebes and the Philippines eastward and is probably identical with $C$. nodiflora Forst. (as I have mentioned in this Journal, 12: 197.1931), whereas C. Junghuhniana Miq., ranging from eastern Java to Timor, is closely allied to certain Australian species (e.g. C. stricta).

A similar case of Australian-Papuan types found in western Malaysia which manifestly represents a continuous distribution is that of the genus Deplanchea (cf. Bull. Jard. Bot. Buitenzorg III. 10:218. 1928). Representatives of this genus are now known from Sumatra, the Malay Peninsula, Riouw, Banka, Billiton, Borneo, Celebes, New Guinea, Australia and New Caledonia.

\footnotetext{
's Landos Plantentuin, Buitenzorg, Java.
} 


\section{$2 \mathrm{BHL}$ Biodiversity Heritage Library}

Steenis, C. G. G. J. van. 1939. "New Records of Styrax and Casuarina from the Solomon Islands." Journal of the Arnold Arboretum 20(2), 220-221. https://doi.org/10.5962/p.185409.

View This Item Online: $\underline{\text { https://www.biodiversitylibrary.org/item/33596 }}$

DOI: https://doi.org/10.5962/p.185409

Permalink: https://www.biodiversitylibrary.org/partpdf/185409

\section{Holding Institution}

Missouri Botanical Garden, Peter H. Raven Library

\section{Sponsored by}

Missouri Botanical Garden

\section{Copyright \& Reuse}

Copyright Status: In copyright. Digitized with the permission of the rights holder.

Rights Holder: Arnold Arboretum of Harvard University

License: http://creativecommons.org/licenses/by-nc-sa/3.0/

Rights: https://biodiversitylibrary.org/permissions

This document was created from content at the Biodiversity Heritage Library, the world's largest open access digital library for biodiversity literature and archives. Visit BHL at https://www.biodiversitylibrary.org. 